\title{
Relationship between Marital Stress and Employees' Job Satisfaction in Hotels of Lagos Metropolis
}

\author{
AKINNAWO, E. OLUTOPE (Ph.D) \\ Department of Behavioural Studies \\ Redeemer's University Ede, Osun State \\ Email: topewutoji@yahoo.com \\ Tel: 2348059430203
}

\section{AKINBOBOLA I. OLUSOLA (Ph.D)}

Department of Behavioural Studies

Redeemer's University Ede, Osun State

Email: solaakinbobola@yahoo.co.uk

Tel: 2348023315058

\section{LAWSON, ELIZABETH OLUFUNKE (MMP) \\ Department of Behavioural Studies \\ Redeemer's University Ede, Osun State \\ Email: lawsonolufunke@gmail.com \\ Tel: 2348055339054}

\begin{abstract}
A number of studies have been done on work related stress factors in association with job satisfaction. However, there is dearth of studies on marital stress, which is a non-work related stress. This study therefore examines possible relationships between marital stress and employees' job satisfaction. A crosssectional survey utilizing an ex-post facto design was adopted in which purposive sampling technique was used for the selection of 220 hotel employees consisting of 113 (51\%) male and 107 (49\%) female. Participants completed structured psychological scales which are Marital Stress Inventory and Job Satisfaction Survey. Data was analysed using statistical methods of Pearson correlation and t-test for independent samples. There existed significant relationship between marital stress and job satisfaction. The result further showed that employees with live-in relatives experienced significantly higher job satisfaction than those who do not have live-in relatives. This study suggested the importance of the interface between work life domain and non-work life domain of the employees.
\end{abstract}

Keywords: Job Attitude, Stress, Work Life Domain, Non-work Life Domain, Hotel.

\section{Introduction}

The concept job satisfaction refers to a positive state resulting from an employee's appraisal of his or her work or work experiences (Locke, 1976), a set of favorable or unfavorable feelings with which employees view their work (Newstrom \& Davis, 1997). Job satisfaction is a job attitude (Spector, 1997) because it is multidimensional (Currivan, 2000; Hulin, \& Judge, 2003) based on affective as well as cognitive and evaluative states (Judge, Heller \& Mount, 2002). Job satisfaction is an employee's positive and/or negative attitudes towards one's job (Greenberg \& Baron, 2008). According to Saari and Judge (2004) cognition and feeling are therefore involved in the evaluation of job. There is presence of both dispositional and 
situational factors on job satisfaction (Heller, Timothy, Judge \& Watson, 2002). Apart from employee's dispositional influences (Judge et al. 2002; Sageer, Rafat, \& Agarwal, 2012) and situational factors especially work itself, cultural influence such as marriage is also linked to one of the causes of employee job attitude for example job satisfaction (Saari \& Judge, 2004). Marriage is a cultural, social and a universal concept. Marriage is a union of a man and a woman, a legal contract by which they both become husband and wife (Hashmi, Khurshid \& Hassan 2007). There is a formal commitment and involvement that establish rights and obligations between husband and wife, to their children, in-laws and relatives. Furthermore, marriage is also primarily an institution in which interpersonal relationship becomes formally acknowledged.

Commitment, involvement and obligation to marriage can be demanding on both husband and wife. Spouses are likely not able to cope with the demands made on one by marriage (Burke, 1987) and experience some adverse psychological and physical reactions. As a result the spouse experiences state of psychological or physiological imbalance termed stress (Omoluabi, 1994). Stress is a state of mental, emotional strain or tension resulting from adverse or demanding circumstances. Sometimes there may be disparity between situational demands and the individual's ability or motivation to meet those demands (Kashif et al. 2016). The inability to cope with or exceed the adaptive capacities which threaten the well being of the spouse experiencing stress in marriage is termed marital stress. Marital stress is a condition of negative effects such as frustration and anxiety which results from aspects of the marriage. For married employees the demands of marriage accompanied by the need to be committed to an organization is likely to constitute a threat to one (Patterson 2002). Some indices of marital stress are household chore stress (McGrane, 2011), financial stress (Mann, 2013), relational stress (Ramirez, 2011), parenting stress (Goldberg \& Perry-Jenkins, 2004) and elder-care stress (Matzek \& Cooney, 2004). Moreover, as the marriage grows older, the length of marriage may bring about increase demands and pressure (Oyewo \& Akanbi 2012).

Latha (2015) opined that employees going through marital stress tend to carry their frustration and anxiety to the workplace; however, one's unfocused attention or lack of motivation affects one's ability to carry out job responsibilities and be productive and may affect satisfaction on the job. In the concept of life domain, marriage (captured as part of family life domain) belongs to non-work life domain while job belongs to work life domain. Experiences, either negative or positive, can be transferred, that is, spillover from one life domain to another. Spillover concerns the transmission of states of well-being from one life domain to the other (Westman, 2002). Invariably, spillover is at intra-individual level, it takes place within a person but it occurs across one's different life domains (Bakker, Demerouti \& Burke, 2009). Saari and Judge (2004) in spillover theory purported that there is interface between non-work life domain and work life domain; that is non-work life spillover with work life experiences and vice versa. In fact, the theory suggested that the relationship between non-work life and work life experiences is reciprocal. One of the effect of non-work life and work life experiences is work related outcomes such as job performance (Lasavani \& Movahedi, 2014); Demerouti, Bakker \& Voydanoff, 2010). Subsequently, non-work life (Demerouti et al. 2010) such as marriage may also interfare with job performance. Since work is a significant part of one's life, the relationship between non-work life and job satisfaction could make sense when considering marital stress in the non-work life domain and job satisfaction in the work life domain. A stressful marriage may spill over into one's work experiences, work evaluations and influence job attitude such as job satisfaction.

An employee may experience increased levels of stress as one juggles marriage and work responsibilities. This is pointing to the fact that there are likely to be the inevitable presence of spillover from marriage to work and vice-versa. This is a condition that could occur generally with married employees and specifically among married employees who work in hotels. Hotel sector belongs to the hospitality industry which is an example of a service oriented industry. The hotel is so unique because it is highly labour intensive, has no routine holiday and needs to be opened for work every week, day and hour. The hotel employees are expected to be at work irrespective of non-work life domain stress; which may affect their attitude or 
satisfaction to job. However, employees are supposed to be polite and cautious with their customers irrespective of what they are going through in their marriage. Hotel employees' job satisfaction is very important to their performance (Borralha, Jesus, Pinto \& Viseu, 2016) their customers and invariably the hotel as an organization for profitability.

Researchers showed that culture is a predictor of employee attitudes (Saari \& Erez, 2002). Other studies found that a strong marriage was a significant predictor of successful balance between work and family life roles (Marks, Bumpass \& Jun, 2004). Some researchers also confirmed that marriage and children have effect on job satisfaction (Bradbury, Fincham \& Beach, 2000; Lillard \& Waite, 2000; Rogers \& May, 2003). Perceived stress was analysed to partially mediate the relationship between negative or positive work-home and home-work interference and job satisfaction (Lourel, Ford, Edey, Hartmann, 2009). Futhermore, studies indicate that job satisfaction affects non-work life, and non-work life also affects job satisfaction (Judge \& Wanatanabe, 1994; (Lasavani \& Movahedi, 2014). Equally, Borralha et al. (2016) found that workplace social support and workplace social resources cushion stress or threat of married employee.

Job satisfaction has long been the concerns of employers because of the impact and influence it has on job performance. Employees' job satisfaction positively influences job performance (Popp, Cumming, \& Goeke-Morey 2009), profitability, financial performance, and efficiency of organizations (Yang, 2010). Employee's job satisfaction is a good measure to evaluate employee attitude and activity of the organization. On the other hand, stress has become a global phenomenon which is virtually experienced by many employees. Stress is not only work related but also non-work related such as in marriage. There is marital stress emanating from one's role as spouse doubling as employee (Crnic \& Booth, 1991) from allocating more time to parenting and childcare (Goldberg \& Perry-Jenkins, 2004) from taking care of either mother-in-law or father-in-law (Matzek \& Cooney, 2009) and from live-in relatives who share in division of household labour ( McGrane, 2011). These indices may also heighten perceived stress of hotel employees. Conversely, a relative living in can render help in childcare and share some household chores thereby reducing the stress of the couple. Marital stress leads to low levels of job satisfaction in the workplace. Low satisfaction levels (Cheng, Yang, Wang \& Chu, 2013; Karatepe \& Sokmen, 2006; Yang, 2010; Zopiatis, Constentia \& Theocharous 2014) can lead to employee turnover and adverse effect on the organization.

There are researches on varieties of work related stress and job satisfaction in the hospitality industry such as the existence of multiple stressors (Karatepe \& Sokmen, 2006); and the stress felt at work (Kim, Murrmann \& Lee, 2009). A number of studies were carried out on stress specifically in the hotel sector. Previous studies focusing on hotel employees, dwelt on the effect of different types of work related stress such as interpersonal stress (O'Neill, \& Davis, 2011); role stress (Karatepe, \& Sokmen, 2006) and job stress (Ahmad, \& Khanna, 1992) on job satisfaction. Studies of work related stress of hotel employees and job satisfaction were carried out in many countries including India (Anbazhagan, Soundar-Rajan \& Ravichandran, 2013); North Cyprus (Karatepe, 2010); Russia (Antonova, 2016); Republic of Korea (Kim et al. 2009); Spain (Santa Cruz, López-Guzmán \& Cañizares, 2014); China-Taipei City (Tsai, Cheng \& Chang, 2010). Furthermore, Demerouti, Bakker \& Voydanoff (2010) found that home life, that is, nonwork life may facilitate job performance; it is necessary therefore to find out if non-work life interferes with job satisfaction.

However, there is a dearth of literature on the influence of marital stress on employees' job satisfaction. The focus of this study therefore is on hotel employees in Lagos metropolis and the need for investigation of the relationship between marital stress and job satisfaction of hotel employees. Lagos is the commercial capital of Nigeria and invariably the hotel capital of the oil rich nation, where visitors abound. The importance of hoteliers and employees attending to these visitors are crucial to the problem of the study. 
From the ongoing, the following hypotheses were tested:

1. There will be significant negative relationship between marital stress and job satisfaction

2. There will be significant negative relationship between length of marriage and job satisfaction.

3. Employees who are not involved with elder-care will have significant higher level of job satisfaction than employees involved with elder-care.

4. Employees with live-in relatives will have significant higher level of job satisfaction than employees without live-in relatives.

\section{Materials and Methods}

The study adopted cross-sectional survey utilizing an ex-post facto design. Data were collected from selected hotels in Lagos Metropolis. The variables of interest are marital stress as the independent variable and job satisfaction as the dependent variable.

\section{Participants}

Participants in this study were two hundred and twenty (220) employees from four different hotels in Lagos metropolis. Participants were made up of married, divorced, separated and widowed employees both male and female. Employees that have their child/children outside wedlock referred to as single parent are not eligible because they were never married. The study population used was homogenous in nature, because the research is for a particular section of the population; therefore purposeful sampling technique was used. Purposeful sampling technique is a form of non-probability sampling in which decisions concerning the individuals to be included in the sample are taken by the researcher, based on a variety of criteria. (Oliver \& Jupp, 2006). The reason for using this sample technique is that some potential participants (single employees) may be willing to be interviewed, but may not be able to provide sufficiently rich data.

\section{Procedure}

The objectives of the research were explained to the participants and the benefit of the research to the organization and the employees. Questionnaires were distributed through head of units to the employees in various departments at the hotels. The questionnaires when fully filled were submitted to departmental units and sent to the Human Resource Department for collection by the researcher.

\section{Instruments}

A questionnaire consisting three sections was used in this research. Section A measured demographic data, section B contained a scale that measured employees' job satisfaction and section C contained a scale that measured marital stress.

Marital Stress Inventory (MSI) was developed by Omoluabi (1994) to measure causes of stress among couples and evaluate their stress reaction and level. The scale contained 50 items rated on a 5-point scale with 1 representing "Slight Effect" and 5 representing "Severe Effect". The reliability by the author is Cronbach alpha coefficient of .92 The researcher's test of reliability is Cronbach's Alpha of .96

Job Satisfaction Survey (JSS) developed by Spector (1994) was used to measure employees' job satisfaction. This instrument measured nine aspects of job satisfaction with 36 items. Responses to the items were numbered from 1 representing "Strongest Disagreement" to 6 representing "Strongest Agreement". The author reported reliability using coefficient alpha of .91 (Spector, 1994). The researcher reported reliability using Guttmann Split-half Coefficient .63 


\section{Results}

Socio-demographic characteristics showed that $113(51 \%)$ of the participants were male and $107(49 \%)$ were female. Older participants $(69 \%)$ were those who are 36 years and above; while younger participants (31\%) were 35years and below. All the participants were married with $44.5 \%$ married for 10 years and above and $55.5 \%$ for below 10 years.

\section{Test of Hypotheses}

\section{Hypothesis One}

As presented in Table 1, there was significant negative correlation between marital stress and job satisfaction $r_{x y}(220)=-.25, p<.05$. This result supported hypothesis one which stated that there will be a significant negative correlation between marital stress and job satisfaction. Therefore, the hypothesis was accepted.

\section{Hypothesis Two}

As presented in Table 1, there was no significant negative correlation between length of marriage and job satisfaction $r_{x y}(220)=-.06, p>.05$. This result did not support hypothesis two which stated that there will be a significant negative correlation between length of marriage and job satisfaction. Therefore the hypothesis was rejected.

\section{Hypothesis Three}

The result in Table 2 showed that the employees who were not involved in elder-care obtained a higher mean score $(\bar{x}=144.31)$ than those involved with elder-care $(\bar{x}=141.23)$ on the job satisfaction scale. The observed difference in their mean scores was however found not to be significant $\mathrm{t}(118)=-.95,>.05$. This indicated that there was no significant difference of involvement with elder-care on job satisfaction of the employees. This finding, presented in Table 2, did not support hypothesis three, which stated that employees who are not involved with elder-care will have significant higher level of job satisfaction than employees involved with elder-care, therefore the hypothesis is rejected.

\section{Hypothesis Four}

The result in Table 2 showed that the employees with live-in relatives obtained higher mean score ( $\bar{x}$ $=144.25)$ than the employees without live-in relatives $(\bar{x}=137.58)$ on the job satisfaction scale. The observed difference in their mean scores was however, found to be significant $\mathrm{t}(118)=2.54, \mathrm{p}<.05$. This finding presented in Table 2, supported hypothesis four which stated that employees with live-in relatives will have significant higher level of job satisfaction than employees without live-in relatives, therefore the hypothesis is accepted.

\section{Discussion}

The findings of hypothesis one showed that there is a significant negative relationship between marital stress and job satisfaction which means that as employees marital stress increases their job satisfaction decrease. This finding substantiated Fieldler, Rocco, Schroeder and Nguyenk (2000); Oyewo and Akanbi (2012); Rogers and May (2003) in which all researchers reported that increase in marital discord was significantly related to a decline in job satisfaction. Latha (2015) opined that employees going through marital stress tend to carry their frustration and anxiety to the workplace which affects ability to carry out 
one's job responsibilities and satisfaction on the job. This finding indicates that factors affecting job satisfaction are not only within situational factors surrounding job but also cultural factors like marriage.

Table 1: Pearson Correlation Analysis Summary showing the Relationship between Marital Stress, Length of Marriage and Job Satisfaction

\begin{tabular}{|lccc|}
\hline Variable & $\mathrm{N}$ & $\mathrm{r}$ & $\mathrm{p}$ \\
Marital Stress & 220 & -.25 & $<.05$ \\
Job satisfaction & & & $>.05$ \\
$\begin{array}{l}\text { Length of Marriage } \\
\text { Job satisfaction }\end{array}$ & 220 & -.06 & \\
\hline
\end{tabular}

Table 2: t test Independent Analysis Showing the Influence of Elder-Care and Live-in Relative on Job

\begin{tabular}{|llccccc|}
\multicolumn{7}{c}{ Satisfaction } \\
\hline (1) Variable & & $\mathrm{N}$ & Mean & SD & $\mathrm{t}$ & $\mathrm{p}$ \\
Elder-Care & Yes & 176 & 141.23 & 19.14 & -.95 & $>.05$ \\
Elder-Care & None & 42 & 144.31 & 18.37 & & \\
& & & & & & \\
Live-in Relative & Yes & 139 & 144.25 & 17.69 & 2.54 & $<.05$ \\
Live-in Relative & None & 80 & 137.58 & 20.39 & & \\
\hline
\end{tabular}

The finding of hypothesis two showed that there was no significant negative relationship between length of marriage and job satisfaction. This finding supported Meyer and Allen (1997), Bradbury et al. (2000) that length of marriage does not guarantee employee's satisfaction.

The findings of hypothesis 3 indicated that there is no significant difference between job satisfaction of employees involvement with elder-care and those without involvement with elder-care. This finding corroborated Ramirez (2011) that global job satisfaction is quite weak for employees with dependant.

The findings of hypothesis 4 showed that employees with live-in relatives experience significant higher job satisfaction than those who do not have live-in relatives. This result is supported by the findings of (Raminez, 2011; Wolfinger, Mason \& Goulden, 2008). Live-in relatives share in household chores and help with childcare, provide support such that the employee can reduce marital stress and will not have negative spillover from demands of marriage in non-work life domain to work life domain; but therefore higher job satisfaction. It is inevitable that employee experience increased level of marital stress as they combine marriage and work responsibility. The non-work life spill over to work life domain.

\section{Conclusion}

This study authenticated the importance of the interface between non-work life domain, one's marriage and non-work life domain of the employee's job satisfaction. Live-in relatives help in reducing marital stress and negative spillover of non-work life domain to work life domain. It is recommended that management should provide organizational family support for married employees and psycho-educational training for employee and their spouses.

\section{References}

Ahmad, S., \& Khanna, P. (1992). Job stress and job satisfaction of middle level hotel employees. Journal of Personality and Clinical Studies, 8(1-2), 51-56.

Anbazhagan, A. L. J., Soundar R, A., Ravichandran, P. (2013). Work stress of hotel industry employees in Puducherry, India. Asia Pacific Journal of Marketing \& Management Review 2(5), 2319-2836. 
Antonova, E. (2016) Occupational stress, job satisfaction, and employee loyalty in hospitality industry: a comparative case study of two hotels in Russia. Unpublished Master's Thesis submitted in fulfillment of the Degree Master of Science in International Tourism. Modul University, Vienna.

Bakker, A. B., Demerouti, E. \& Burke, R. (2009). Workaholism and relationship quality: A spillovercrossover perspective. Journal of Occupational Health Psychology 14, 23-33.

Borralha, S., Jesus, S. N., Pinto, P., \& Viseu, J. (2016). Job satisfaction in hotel employees: A systematic literature review. Journal of Spatial Organisational Dynamic 4, 1, 4-20.

Burke, W. W. (1987) Organization Development: A Normative View. Reading, MA: Addison- Wesley.

Bradbury, T. N., Fincham, F. D., \& Beach, S. R. H. (2000). Research on the nature and determinants of marital satisfaction: A decade in review. Journal of Marriage and the Family, 62(4), 964-980.

Cheng, P., Yang, J., Wang, C., \& Chu, M. (2013). Ethical contexts and employee job responses in the hotel industry: The role of work values and perceived organizational support. International Journal of Hospitality Management, 34, 108-115.

Crnic, K. A., \& Booth, C. 1. (1991). Mothers' and Fathers' perceptions of daily hassels of parenting across early childhood. Journal of Marriage and the Family, 61, 611-625.

Currivan, D. (2000). The causal order of job satisfaction and organizational commitment in models of employee turnover. Human Resource Management, 9, 495-524.

Demerouti, E. Bakker, A. B. \& Voydanoff, P. (2010) Does home life interfere with or facilitate performance? European Journal of Work and Organisational Psychology19, 128-149

Fieldler, E.R, Rocco, D., Schroeder, P, \& Nguyenk D., (2000). The relationship between aviators' Homebased stress to work and self-perceived performance.DOT/FAA/AM00/32. Oklahoma City, Oklahoma, US.: U.S. Federal Aviation Administration (FAA) Civil Aeromedical Institute (CAMI; now the Civil Aerospace Medical Institute), 1-7.

Goldberg, A. E., \& Perry-Jenkins, M. (2004). Division of labour and working-class women's well-being across the transition to parenthood. Journal of Family Psychology, 18, 225-236.

Greenberg, J., \& Baron R. A. (2008). Behavior in Organisations. New York, NY: Pearson Prentice Hall,

Hashmi, H. A., Khurshid, M., \& Hassan, I. (2007) Marital adjustment, stress and depression among working and non-working married women. Internet Journal of Medical Update, 2 (1), 19-26.

Heller, D., Timothy, A., Judge, T. A. \& Watson, D. (2002). The confounding role of personality and trait affectivity in the relationship between job and life satisfaction. Journal of Organisational Behaviour 23(7), 815-835.

Hulin, C. L., \& Judge, T. A. (2003). Job attitudes. In W. C. Borman, D. R. ligen, \& R. J. Klimoski (Eds.), Handbook of Psychology: Industrial and Organizational psychology (pp. 255-276). Hoboken, NJ: Wiley.

Judge, T. A., Heller, D. \& Mount, M. K. (2002). Five-factor model of personality and job satisfaction: a meta-analysis. Journal of Applied Psychology 87(3), 530-41.

Judge, T. A. \& Watanabe, S. (1994). Individual differences in the nature of the relationsip between job and life satisfaction. Journal of Occupational and Organisational Psychology, 67, 101-107

Karatepe, O. M. (2010). Role stress, emotional exhaustion, and job satisfaction in the hotel industry: The moderating role of supervisory support. Hospitality Review, 28(2).

Karatepe, O. M., \& Sokmen, A. (2006). The effects of work role and family role variables on psychological and behavioural outcomes of frontline employees. Tourism Management, 27, 255-268.

Kashif, M, Fatima, M, Nisa, B. Hassan, S. Ghazal, I. Aslam, F (2016) Level of Stress and its association with socio-demograpic. Factors among medical students of Rawa Ipindi medical college. International Journal of Indian Psychology 4(1), 82.

Kim, B., Murrmann, S., \& Lee, G. (2009). Moderating effect of gender and organizational level between role stress and job satisfaction among hotel employees. International Journal of Hospitality Management, 28, 612-619.

Lavassani, K. M., \& Movahedi, P. (2014) Developments in theories and measures of work-familiy. Contemporary Research on Organisational Management and Administration 2, 6-19. 
Latha, J. R. (2015) Skill development and career needs of school dropout adolescents and youth: A study conducted among the rural villages in Tamilnadu. International Journal of Life Skills Education ISS. 23.

Lillard, L., \& Waite L. (2000). Marriage, divorce and the work and earning careers of spouses. Michigan retirement research Centre. University of Michigan. http://www mrrc isr umich edu mrrc@umich edu

Locke, E.A. (1976). The nature and causes of job satisfaction. In M. D. Dunnette, (Ed.), Handbook of industrial and organizational psychology (pp 1297-1343) Hoboken, NJ: Wiley..

Lourel, M., and Michael T. Ford, and Claire Edey , Anne Hartmann (2009) Negative and positive spillover between work and home: Relationship to perceived stress and job satisfaction. Journal of Managerial Psychology, 24(5), 438-449

Mann, S. (2013). Third wave feminism's unhappy marriage of postructuralism and intersectionality theory. Journal of Feminist Scholarship 4.

Matzek, A. E., \& Cooney, T. M. (2009). Spousal perceptions of marital stress and support among grandparent caregiver: variations by life stage. International Journal of Aging and Human Development 68, 2, 109 -126.

McGrane, M. (2011). Post-Traumatic Stress Disorder in the Military: The Need for Legislative Improvement of Mental Health Care for Veterans of Operation Iraqi Freedom and Operation Enduring Freedom. Journal of Law and Health Law, 184-214.

Marks, N., Bumpass, \& Jun, H. (2004). Family roles and well-being during the middle life course. In O.G. Brim, C. D. Ryff, \& R. C. Kessler (Eds). How healthy are we? A national study of well-being at midlife (pp514-549).

Meyer, J. P. \& Allen, N. J. (1997). Commitment in the workplace: Theory, Research and application. Sage publication.

Newstrom, J. W., \& Davis, K. (1997). Organizational Behavior: Human Behavior at Work. Boston, Mass: McGraw-Hill Companies.

Oliver, P. Jupp, V. (2006) Purposive sampling. In C. Edmunds (Ed.), The sage dictionary of social research methods (pp. 244-245) London: Amason.

O`Neil, J. W., \& Davis, K. (2011). Work stress and well-being in the hotel industry. International Journal of Hospitality Management, 30, 385-390.

Omoluabi, P. F. (1994). Psychological causes and remedies of single parenthood. Paper Presented at the First APQUEN Conference, Enugu, Nigeria.

Oyewo, N. \& Akanbi, S. (2012). Marital spillover as predictor of performance of job performance among married civil servants in Oyo state, Nigeria, European Journal of Humanities and Social Sciences, 14(1).

Patterson J., (2002). Family resilience and family stress theory. Journal of marriage and the family, 64(2), 349-360.

Popp, L., Cumming E. \& Goeke-Morey, M. (2009). For richer, for poorer; money as a topic of marital conflict in the home. Family Relations Journal, 58, 91-103.

Ramirez, T. J. (2011). Factors that contribute to overall job satisfaction among faculty at a large public land-grant university in the mid-west. Unpublished Graduate thesis Dissertation. Iowa State University.

Rogers, S. J \& May, D. C. (2003). Spillover between marital quality and job satisfaction: long term pattern and gender differences, Journal of Marriage and Family 65(2) 482-495.

Saari, L. M. \& Erez, M. (2002). Cross-cultural diversity and employee attitudes. Paper presented at the Seventeenth Annual Conference of the Society for Industrial and Organisational Psychology, Toronto.

Saari, L. M. \& Judge T. A. (2004) Employee attitudes and job satisfaction. Human Resource Management 43(4), 395-407

Sageer, A., Rafat,S., \& Agarwal, P. (2012) Identification of variables affecting employee satisfaction and their impact on the organization IOSR. Journal of Business and Management, 5(1), 32-39

Santa Cruz, F. G., López-Guzmán, T., \& Cañizares, S. M. S. (2014). Analysis of job satisfaction in the hotel industry: A study of hotels in Spain. Journal of Human Resources in Hospitality \& Tourism 13, (1). 
Spector, P. E. (1997). Job satisfaction: Application, assessment, causes, and consequences. Thousand Oaks, CA.: Sage.

Tsai, M., Cheng, C. \& Chang, Y. (2010). Drivers of hospitality industry employees' job satisfaction, organizational commitment and job commitment by African. Journal of Business Management 4(18), 4118 - 4134.

Westman, M. (2002). Crossover of stress and strain in the family and in the workplace. In P. L. Perrewe \& D. C. Ganster (Eds.), Research in occupational stress and well-being (2) (pp. 143-181). JAI Press/Elsevier Science.

Wolfinger, N. H., Mason, M. A., \& Goulden, M. (2008). Problems in the pipeline: Gender, marriage, and fertility in the Ivory Tower. Journal of Higher Education, 79(4), 388- 405.

Yang, J. (2010). Antecedents and consequences of job satisfaction in the hotel industry. International Journal of Hospitality Management, 29, 609-619. 